\title{
THE BROW-ANTLERED DEER OF MANIPUR
}

\author{
October and November 1959 and March 1960 \\ REPORT BY E. P. GeE
}

The full report was published in the Journal of the Bombay Natural History Society, December 1960. This is a shortened version.

\section{INTRODUCTION}

This report deals with Cervus eldi eldi McClelland, 1842, the Manipur (India) subspecies of a very beautiful deer which is only found in the south-western portion of the Logtak Lake in Manipur - a State of the Indian Union. In recent years it has become very rare, and for its preservation it became evident that more information about its numbers, habits, habitat and so on was needed. This survey, sponsored by the International Union for the Conservation of Nature, and approved of by the Indian Board for Wild Life, attempts to supply the required information, and makes recommendations for ensuring the continued survival of this sub-species.

The three sub-species of the Brow-antlered Deer may be briefly enumerated as follows :

(i) The Manipur sub-species, Cervus eldi eldi McClelland, 1842 : Now found only in one small 10 square mile portion of the valley area of Manipur State in India. Locally known as sangai or shangai, which means "the animal that looks at you ". The stags commence shedding their antlers late in June, and new antlers are in velvet till November when they become full size. In December they become hard and clear of velvet and remain so till early June. The rutting season is at its height in February and March, and the fawns are born in October and November. Fuller descriptions of its habitat and habits are given later in this report.

(ii) The Burma sub-species, Cervus eldi thamin (Thomas), 1918 : Found in Upper and Lower Burma, and also possibly in parts of Thailand. Locally known as thamin or thameng. In $1955 \mathrm{U}$. Tun Yin made a compilation of reports received from Forest Officers, and concluded that there were then 3,000 to 3,500 thamin in the Union of Burma; and L. M. Talbot, who visited Burma in 1955, gave an estimate of 2,500 to 3,000. But 
subsequent reports from Burma indicate that the number may now be considerably less, for although the thamin was declared by the Government of the Union of Burma in 1956 to be a "completely protected species", it is feared that a great deal of illicit shooting is still going on.

(iii) The Thailand sub-species, Cervus eldi siamensis Lydekker, 1915 : Found in Thailand and Viet Nam (and possibly in Cambodia, Laos, Viet Minh and Hainan). Known in Thailand as la-ong la-mang, or la-mang for short (a big stag with good antlers is usually called la-ong, and a young stag or hind la-mang). In Cambodia it is known as la-miang. Formerly it abounded on the open plains and in the deciduous forests of Thailand, but now it is reliably reported by Dr. Boonsong Lekagul in litteris (May, 1960) that it is on the verge of being lost. Only a few herds of four or five head are to be seen at Nang Rong in the north-east and at Chieng Karn in the north, and it is doubtful if these can be saved unless the Thai Government can take quick and effective steps to protect them.

The stags of the Brow-antlered Deer, or Eld's Deer, are described as standing about $4 \mathrm{ft}$. high at the shoulders, and weighing from $210 \mathrm{lb}$. to $245 \mathrm{lb}$. The hinds are smaller. The maximum length of the antlers is 42 in. The coat of the stags is rather coarse, and they develop a mane. There is a seasonal change in their coloration, from brown in the winter to chestnut in the summer. The young are spotted; and traces of spots can be seen in adults, even after several years.

This deer is readily distinguished from all other species of deer by the peculiar form of the antlers. These are set in the head at right angles to the pedicle, and the curve of the brow tines is continuous with that of the beams. The antlers of opposite sides are unsymmetrical when compared with one another. The beams are unbranched for some distance, much curved, and finally forked. In older stags the forward bend makes a distinct angle in the beam, while in young stags the curve is more continuous, like a prostrate letter $\mathrm{C}$. The long brow tine makes the stags particularly susceptible to injuries in the head, indeed many have been found to be blind in one eye. The antlers of the Thailand sub-species are generally, if not always, palmated terminally.

The pasterns of the Manipur sub-species are hairless, hard and horny, specially adapted for moving about on swampy ground and for preventing it from sinking through the surface mat of reeds and grasses. The pasterns of the Burma and Thailand sub-species, which live in dry undulating country, are hairy. 


\section{Protection}

Prior to 1891 the Manipur deer were recorded (Alban Wilson, 1924) as having been " preserved by order of the royal family, and any man who was proved to have killed one had his hand chopped off, but after we (the British) took over the affairs of the State the deer were allowed to take their chance, and the Mohammedans who lived in the vicinity were not long in waking up to the fact. They used to mount their buffalo, armed with spears, ride quietly up to the deer, surround them in the heavy grass, and then stick them. ... Luckily a sporting political agent finally issued orders to preserve this rare beast from indiscriminate slaughter....".

In 1934 by order of the Manipur State Durbar it was resolved that no further permits be issued for shooting these deer until further orders, as this animal was in danger of extinction.

In December 1951 the Government of Manipur informed the writer of this report that "enquiries have been made by the Forest Department and it has been found that this deer has become totally extinct and no alive specimen is now available.... In view of what is stated above there is no need to establish a Wild Life Sanctuary at present". Accordingly the writer informed the International Union for the Conservation of Nature that this sub-species had been reported as extinct. But he, as well as Lieut.-Col. R. W. Burton and Shri P. D. Stracey (then Senior Conservator of Forests, Assam), continued their efforts to obtain further information and to protect the deer in the event of their being found.

Subsequently it was found that the deer did actually exist, and in October 1953 the whole of the Logtak Lake area was closed to shooting and declared a Sanctuary by the Government of Manipur in order to protect it. Later on it was pointed out that it was unnecessary to close the whole of the lake to shooting as this deprived many bona fide sportsmen of their legitimate goose- and duck-shooting, and consequently in July 1954 the Logtak was opened to shooting-except the southern portion where the deer existed, which was made into a Sanctuary of approximately 20 square miles in extent. The area became reduced and in 1959 this Sanctuary called Keibul Lamjao was surveyed and officially reported as being about $10 \frac{3}{4}$ square miles.

\section{Geography and Ecology}

Manipur, now a Territory of the Indian Union, lies between Burma and the north-eastern portion of India and consists of 
a valley area, which is surrounded by a hills area, between $23^{\circ} 47^{\prime}$ and $25^{\circ} 41^{\prime}$ north latitude and $93^{\circ} 6^{\prime}$ and $94^{\circ} 48^{\prime}$ east longitude. The broad open valley is about 750 square miles in extent, and about 2,500 feet above sea-level; a peculiar feature of this plain is the existence of many small hillocks dotted over the whole area. The hills area is about 7,500 square miles in extent, rises up to some 10,000 feet, and consists of ranges of hills mostly running north and south.

The six large streams, as well as numerous small ones, which drain from the hills into the central plain, all combine to flow out again southwards through a narrow gorge into the Chindwin river in Burma. Consequently the southern portion of the valley contains a number of lakes and marches, with variations in their conformation due to changing flood levels and growths of reeds, grasses and floating water weeds.

The Logtak is the largest of the lakes, and is over 25 square miles in extent. Smaller lakes or jheels are dotted about, some of which dry up in the dry season either completely or with just a few pools of water remaining. A large part of the valley area is under a few inches of water during the rainy season, April to mid-October, and rice is extensively cultivated.

From figures given by D. B. Deb (1960) for Imphal, which is only 20 or so miles from Keibul Lamjao Sanctuary, the average annual rainfall is 48 inches, and the mean daily humidity is highest in August with 81 per cent and lowest in March with 49 per cent. The maximum temperature is $34 \cdot 44^{\circ}$ and the minimum $1 \cdot 66^{\circ}$ Centigrade. Frost is common in the valley during December and January.

Keibul Lamjao Sanctuary consists of roughly 10 square miles of "swamp". I have purposely enclosed the word swamp in inverted commas, because it must be explained at the outset that this is no ordinary swamp. It is a floating swamp. Tall reeds and grasses and other plants grow on a mat of dead or decaying vegetation; and this mat actually floats on the lake with approximately one-fifth of it above the surface of the water and four-fifths of it below.

The habitat of the deer near the shore of the Logtak Lake consists of what the Manipuris call phumdi. Phum or phumdi is a mat of organic matter in which reeds and grasses grow, often up to $\mathbf{1 5}$ feet or more. It is subdivided into phumdi arupa (sinking) and phumdi ataoba (floating). There is a 7 foot long implement called phumlen thangol for cutting phumdi when a canal or passage is made. Phumdi varies in thickness from 6 inches to about 5 feet, and where it is thick a man can walk 


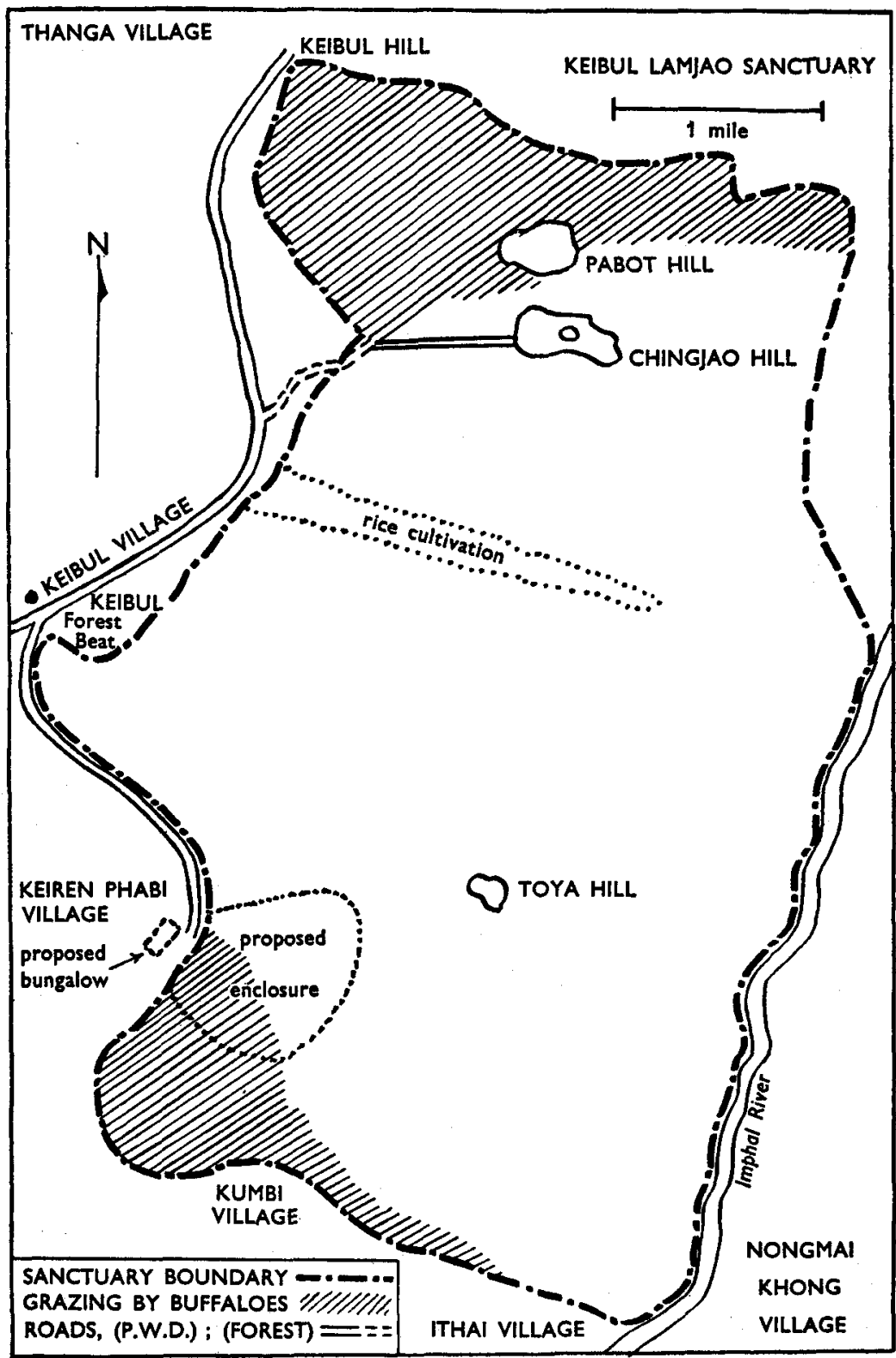


through he will sink to his knees or further in the soft mat. Should he accidentally tread on the mat where it is thin, he will go right through it into the water beneath.

Only the most enthusiastic of sportsmen went after this deer. To quote from Lieut.-Col. H. S. Wood : " No other animal could exist in such swamps. ... The action of this deer is very peculiar. Instead of bounding with fore- and hind-feet coming on to the ground at the same time, it seems to be proceeding on its hind legs, the body being held almost vertical. This action prevents it from sinking in the quagmire ..."

In places where the phumdi (of the ataoba or floating type) is non-existent, a reed (Saccharum latifolium) grows on the bed of the lake in the sinking phumdi (phumdi arupa), and approximately 5 per cent of the area of the sanctuary consists of this. It is eaten by the deer and by domestic buffalo. The reeds and grasses which grow on the floating phumdi are as follows :

\begin{tabular}{|c|c|c|c|c|c|c|}
\hline Phragmiles karka & & . & 45 & $\mathbf{r c}$ & f t & net \\
\hline singut (not yet iden & & & 25 & ", & ", & ", \\
\hline Saccharum munja & . & & 15 & $"$ & $"$ & $"$ \\
\hline Alpinia allughaf & - & & 5 & ," & ", & ,, \\
\hline Saccharum procerum & . & . & $\mathbf{2}$ & ", & ", & , \\
\hline Miscellaneous & . & - & $\mathbf{3}$ & ," & $"$ & $"$ \\
\hline
\end{tabular}

There is no water hyacinth in the sanctuary area, except a very small amount near the edge. Presumably it cannot compete with the thick reeds and grasses which are listed above. The average thickness of the phumdi in the sanctuary area in October is about 3 to 4 feet, with about 4 to 5 feet of water underneath. In time of floods this 4 to 5 feet average would become 5 to 6 feet; while in March at the driest time of the year it would be 2 to 3 feet or even less, and in very shallow places the phumdi would then be resting on the ground.

The small hilly area included in the sanctuary to the southwest is mostly denuded of vegetation by the overgrazing of village cattle. To this high ground the deer sometimes move in times of very heavy rain which takes time to seep through the phumdi. As soon as this surface flooding of the phumdi has disappeared, due to the phumdi eventually floating again on the surface of the lake, the deer return.

Wild pig and a few Hog Deer share this floating sanctuary with the Brow-antlered Deer. I was informed that Wild Dog do not and cannot exist in this area, but that occasionally a Leopard has been observed in it. Of bird life, only the smaller reed-dwelling species were observed. Larger wading and swimming birds appeared to be non-existent, as there are no open patches of water in the sanctuary. 


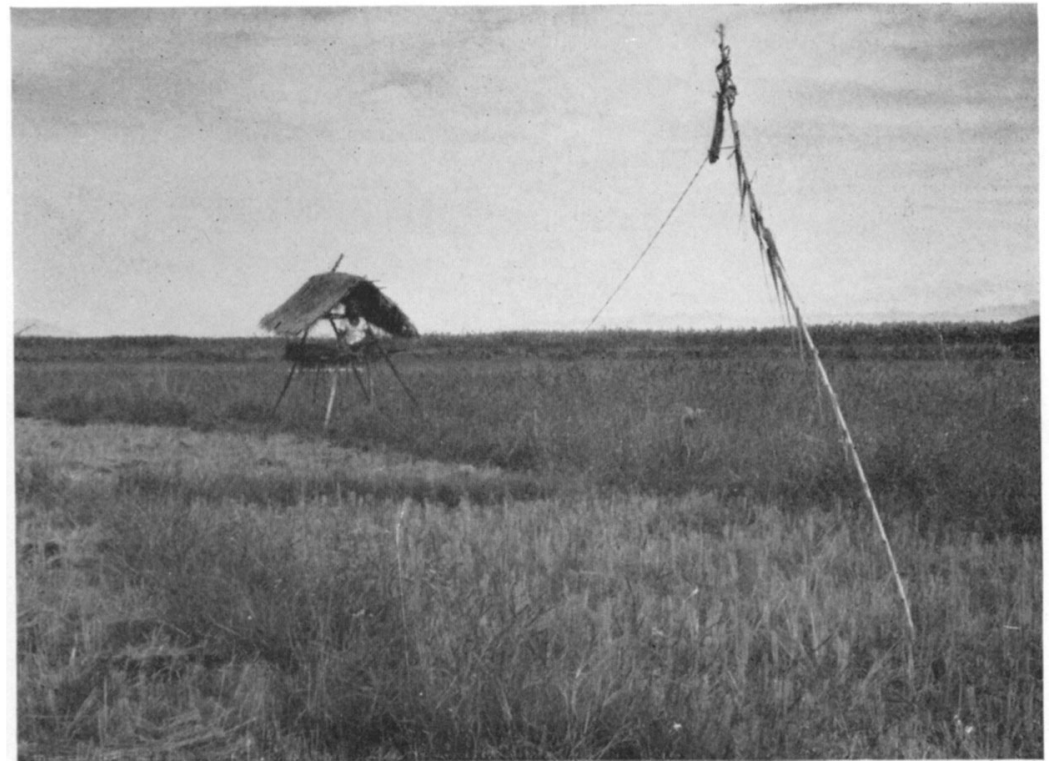

SHELTER AND CONTRIVANCE FOR DRIVING

Photo: E. P. Gee. WILD PIGS FROM RICE FIELDS.

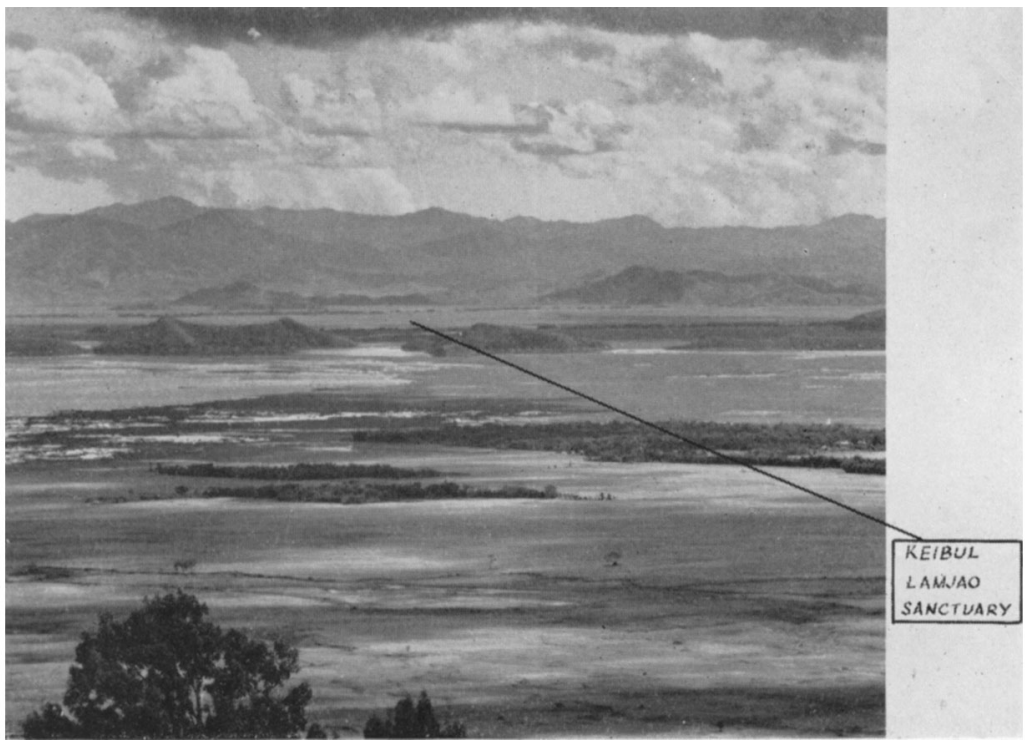

THE LOGTAK LAKE.

Photo: E. P. Gee. 


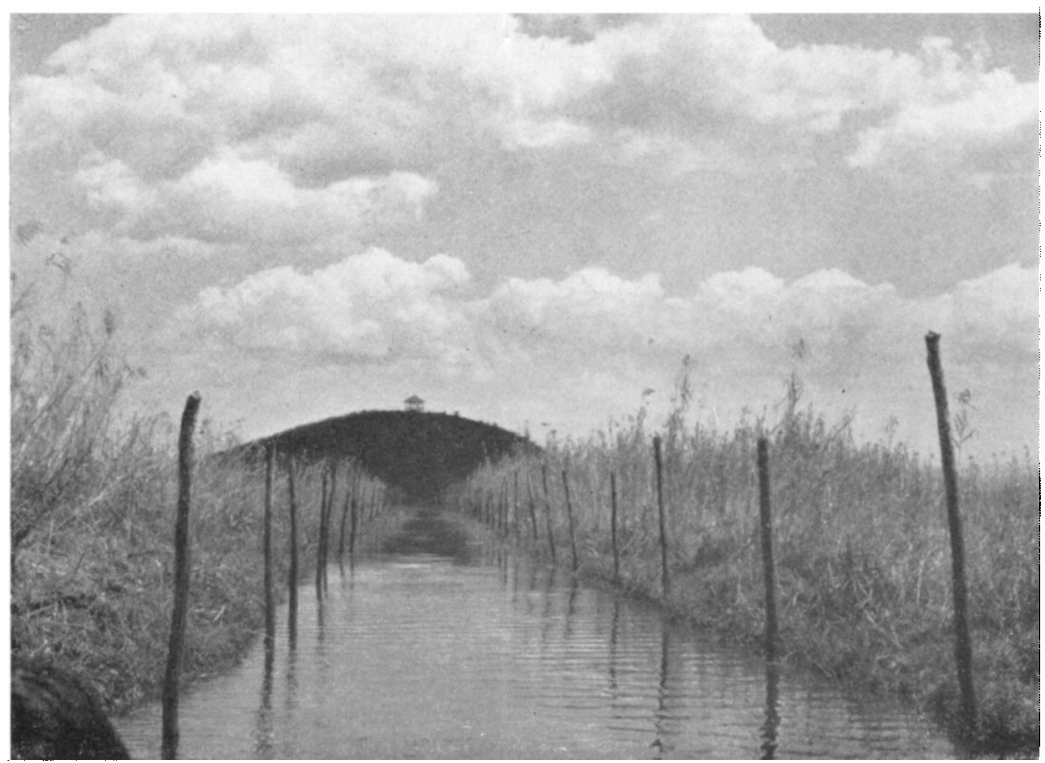

Photo: E. P. Gee.

KEIBLI, LAMJAO CANAL AND OBSERVATION TOWER.

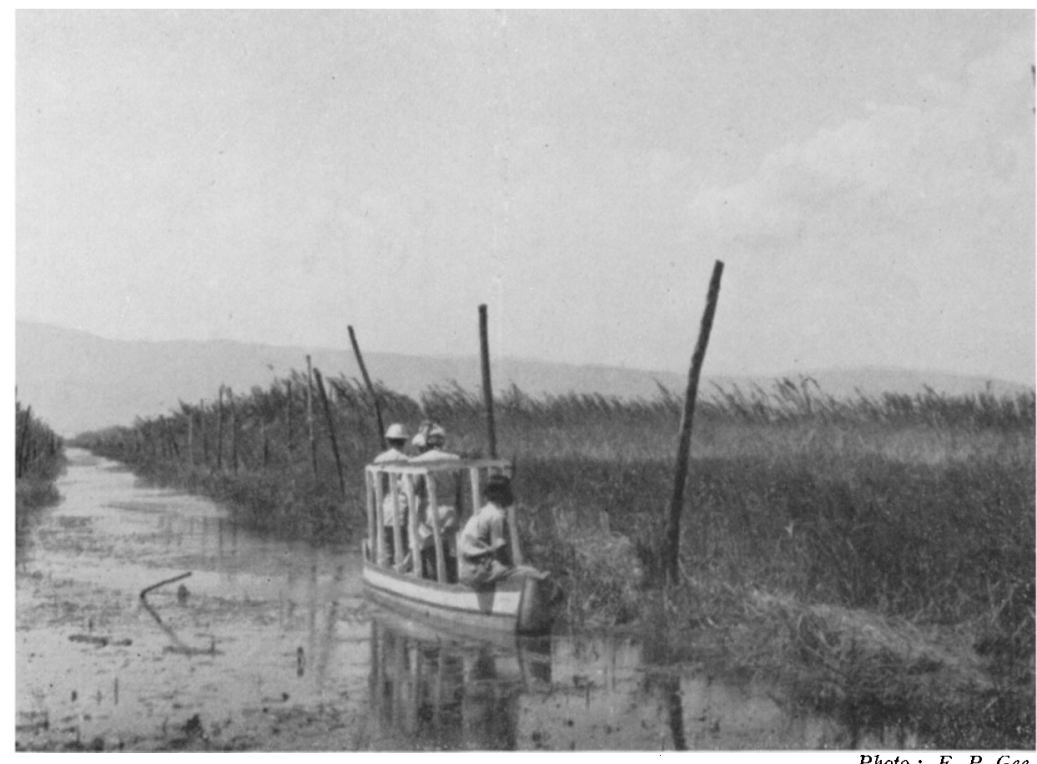

IN THE KEIBUL LAMJAO SANCTUARY 


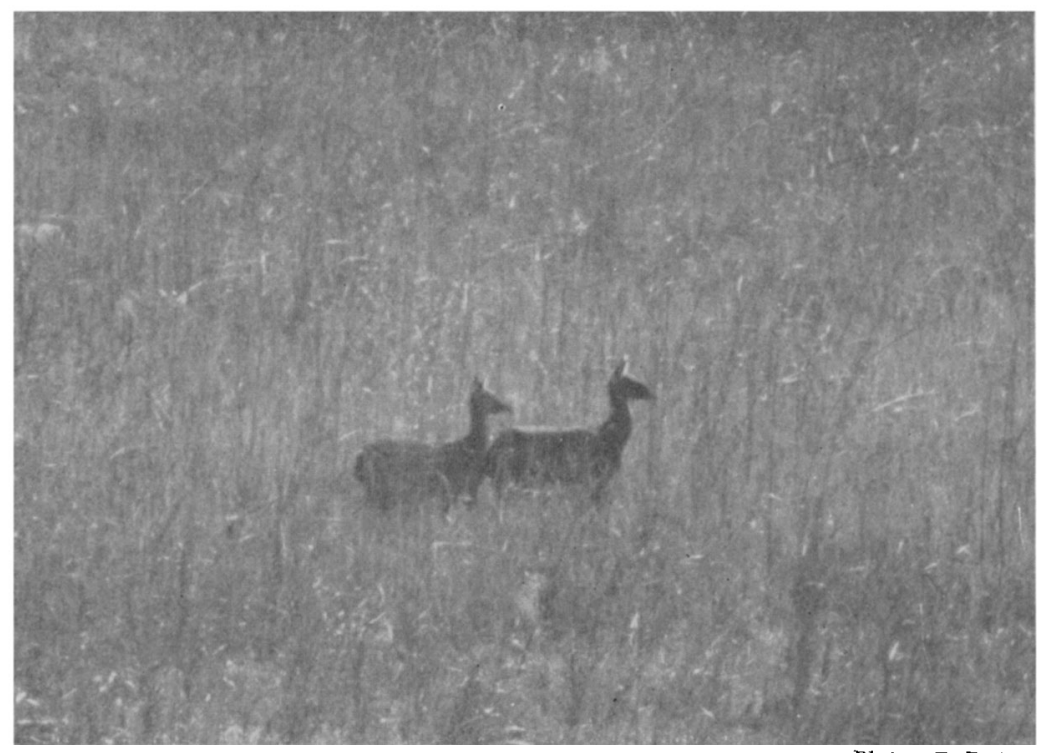

BROW-ANTLERED DEER IN KEIBUL LAMJAO.

Photo: E. P. Gee.

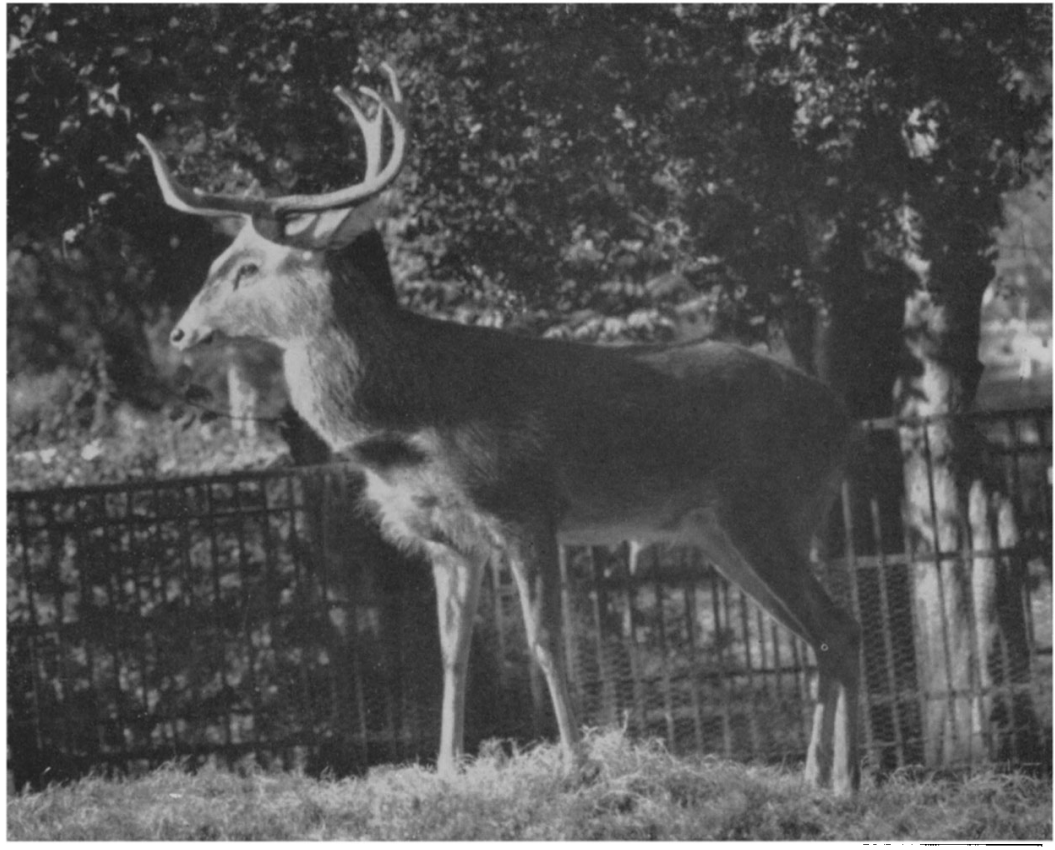

THE BROW-ANTLERED DEER.

Photo: E.P.Gee 
There are villages all along the western and southern boundaries of the sanctuary, with large numbers of buffalo and cattle and with extensive rice cultivation. Cattle cannot enter the phumdi, but domestic buffaloes graze over about $2 \frac{1}{2}$ square miles of the sanctuary. A strip of waste land along the western side of the sanctuary has been encroached on and cultivated, and a narrow wedge of approximately 60 acres right inside the sanctuary has been cultivated by these villagers. Fishing from approximately 1,000 narrow dug-out boats is done throughout the sanctuary area, along the narrow tracks where the phumdi is very thin or non-existent. From the end of the forest road to the edge of the sanctuary, to the hillock named Chingjao Hill on which the observation hut has been built, a canal has been cut through the 5 feet thick phumdi. This canal is 15 feet wide and 2,800 feet long, and cost over Rs. 6,000 (£450) to cut.

\section{Administrative and Political}

In the Manipur Administration, which is under the Chief Commissioner, the Secretary (Miscellaneous) has charge of the Forest Department. The Head of this Forest Department is the Chief Forest Officer, and the Keibul Lamjao Sanctuary has been placed under the Range Officer, Moirang, since 1st January 1959. The Forest Staff in charge of the Sanctuary at the time of my two visits consisted of one Forester, one Forest Guard and one Game Chaprassi.

In the last census the population of Manipur was given as (approximately) 600,000, of which 200,000 were in the hills area, and 400,000 in the valley area. Of these 400,000 in the plain, 200,000 were in Imphal town itself and 200,000 out in the villages. Since then the above populations have probably increased by 50 per cent due to natural increase and the influx into Manipur of displaced persons, Nepalis, and others. It will be seen, therefore, that the valley area is very thickly populated, and all the available land is under rice cultivation.

The Keibul Lamjao Sanctuary itself is flanked on the northwest, west and southern sides by Thanga, Keibul, Kumbi and other villages, the inhabitants of which are fortunately Manipuris who are vegetarian in diet and therefore do not hunt or kill the deer. To the north-east of the sanctuary, however, there are four Mussulman villages whose inhabitants would (if given the chance) hunt and kill the deer. I was informed that no guns were possessed by any of the villagers.

Three cases, I was told, of " encroachment in the sanctuary 
and of shooting animals" were detected and dealt with in 1955-56, and none in the subsequent years.

The fishing rights in the sanctuary area are auctioned annually and were sold during the current year for Rs. 3,000 (£225). Reed cutting, mainly on the eastern side of the sanctuary, was sold in two lots for Rs. 800 ( $£ 60$ ) and Rs. 700 ( $\$ 52$ 10s.). Fishing in small dug-outs in the sanctuary probably does not unduly disturb the deer, and may be regarded as a long-established "right" of the local inhabitants with which it would be inadvisable to interfere.

Similarly reed cutting is a local economic necessity and has been done since time immemorial, as the reeds are used for the building of walls of houses and as firewood; and the cutting and burning of reeds results in fresh growth, which is palatable to the deer. Incidentally, I found during my March visit that burning off the reeds and grasses was only partially successfulunless they had previously been cut and left in situ. Cutting followed by removal of reeds and grasses would probably not facilitate burning, but would none the less produce new shoots.

Regarding the narrow strip of waste land along the western edge of the sanctuary, amounting to about 1 square mile, I was told that the villagers were claiming it and cultivating it, and that there had been some dispute between the Forest Department who wished to include it in the Sanctuary and the Revenue Department who considered that it should be opened up for cultivation. I understand that it will now be difficult, if not impossible, to prevent cultivation here. There is a thin wedge of rice cultivation right in the centre of the sanctuary, amounting to some 50 to 60 acres across, which should be stopped if possible.

I found that the local people, even educated persons, knew very little about deer and other wild life. The Mohammedan shikaris, who have for generations accompanied the sportsmen who have come here for goose, duck (and deer) shooting, are the only people who have a working knowledge of "game" animals and birds.

When I asked what were the reactions of the local villagers to the creation of the sanctuary, I was told that those people who were cultivating the strip of waste land along the western edge and the central thin wedge inside the sanctuary objected. Otherwise there were no adverse reactions except for those whose rice fields were raided by wild pigs from the sanctuary. The owners of the domestic buffaloes which grazed within the boundaries of the sanctuary would also probably protest if deprived of this facility. 


\section{General Account of the Survey}

First of all, a permit to visit Manipur was obtained-a formality obligatory on all who are not Indian nationals, mainly because of the Naga Hills being a " disturbed " area. The fullest co-operation of the Forest Department had previously been offered to me by the Chief Forest Officer. On 21st October, at the end of the monsoon, I motored in my Land Rover (with trailer) to Imphal, via Kaziranga, Garampani, Dinapur, Kohima and Mao. From Dimapur to Kohima it was obligatory to travel in the daily armed military convoy, as the road to Manipur runs through the Naga Hills. One day was spent in Imphal in order to contact the Chief Forest Officer, and the Deputy Commissioner (who is Chairman of the Wild Life Board there). The nights of the 26th and 28th to 31st were spent at Moirang, which is 26 miles from Imphal and 4 miles from Keibul Lamjao Sanctuary-the object of my tour.

It was fine, sunny weather. The rice in the fields was still green, and the road to the sanctuary muddy after the monsoon rains. We saw many small shelters in the fields with a contrivance for driving away wild pigs. At the end of the forest road to the sanctuary, a boat met us and took us along the canal through the phumdi. Numerous light brown mosquitoes and two leeches failed to discourage me. On arrival at the observation tower on the 150 feet high hillock known as Chingjao Hill, I found that a good view was obtainable of the sanctuary, which looked like a sea of reeds and grasses.

As it had taken us two hours to reach this spot, partly by Land Rover and partly on foot, and as it was only from this observation tower on the hillock that there was a chance of seeing anything, I decided to remain there all that day and for the night, in order to avail myself of evening and early morning opportunities of seeing deer. There were protests from the Forest Staff and villagers, about danger from wild pigs, about discomfort from mosquitoes, and above all about the existence of evil spirits at that place at night. These did not deter me, and I sent back for the necessary bedding and food.

Several wild pigs were seen during the day; and very early on the following morning one of the men accompanying me had a close view of a stag and a hind, and later another hind, near the canal. Afterwards, on being shown the antlers of a Hog Deer and of a Brow-antlered Deer, he unhesitatingly indicated that it was the latter that he had seen. In another direction I myself saw three light-coloured hinds in the distance which were almost certainly Brow-antlered Deer. 
My main impression of the sanctuary was that it was a most impenetrable place. Even in a large boat while travelling along the wide canal, we were bitten by mosquitoes and leeches; how much more difficult and uncomfortable would it have been to see the sanctuary by inching one's way in a tiny two-man unstable dug-out boat through the thick sea of grasses and reeds growing up to some $\mathbf{1 5}$ feet in height, with only a very remote chance of obtaining even a fleeting glimpse of a deer? When I referred to this difficulty, the reply was that March, not October, was the best time to visit the sanctuary, when some of the grasses and reeds had been burnt off and the water-level was lower.

So I decided to visit the sanctuary again in mid-March, the driest time of the year in these parts. The Chief Forest Officer agreed to try and conduct some kind of census of the deer when I arrived, and we discussed ways and means of doing this.

When I arrived in March $1960 \mathrm{I}$ was surprised to find that the level of the lake had only sunk about 2 feet since last October, and that there was still a great deal of water everywhere-and the phumdi still floating on it. Some patches of reeds and grasses had been burnt off by the Forest Staff without previous cutting, and were only partially burnt. Some other patches had been cut and then burnt off, more thoroughly. New shoots were appearing everywhere, and the places where Saccharum latifolium grew in the bed of the lake (and not on the phumdi) were bright green with new growth. But, seen as a whole from the observation hill, the sanctuary still appeared to be a sea of reeds and grasses, with only small areas of open " ground". There was still a very great deal of cover for wild life, and hopes of doing a census of the deer rapidly faded away.

Carefully searching the area with binoculars, I saw a stag and hind Brow-antlered Deer about half a mile away, in the grass. In another place two half-grown fawns were playing, almost dancing round in circles, while their mothers grazed nearby-unmistakably Brow-antlered Deer.

Twenty Manipuri villagers had been arranged to drive selected areas for conducting a census. These I decided to send out so that they could form a line and drive a representative area of about a quarter of a square mile towards the hillock. I remained on the hillock with binoculars to observe results, as from the ground nothing can be seen except the grass immediately in front. The men denuded themselves of all clothing up to the hips and set off-many of them with sticks to probe the phumdi 
for softer places in order to avoid a ducking. Soon they were all splashing their way through the black ooze which came well above the knees.

Out of this area came four Brow-antlered Deer, hinds and fawns, and ten pigs. Two hours had passed by, and the men were not at all in favour of doing any more such drives in such heavy going. On the basis of this very limited investigation I arrived at the following conclusion : The total area of the sanctuary was $10 \cdot 75$ square miles. Deduct from this the area grazed by domestic buffalo $2 \cdot 50$ square miles, the area of waste land and rice land under cultivation 1 square mile, and the hill area $\mathbf{0} \cdot 25$ of a square mile, and then 7 square miles remained. At the rate of sixteen deer per square mile, the total would be 112 Brow-antlered Deer in the sanctuary, say 100. Similarly $\mathbf{2 8 0}$, or say 300 , wild pig also exist here.

The Indian Swamp Deer, Cervus duvauceli, does not exist and has never existed in Manipur. Barking Deer, Muntiacus muntjak, are found in the hilly, forested places. As for Hog Deer, Axis porcinus, none were actually seen on my two visits to Keibul Lamjao Sanctuary, but there may be some twenty-five present.

The Forest Staff in charge of the Sanctuary and under the Range Officer of Moirang at the time of my first visit were as follows: one Forester (3 months there), one Forest Guard (10 years there), one Game Chaprassi (3 months there). At my second visit, the first two of the above personnel had been changed, and I found : one Forester (17 days there), one Forest Guard ( $1 \frac{1}{2}$ months there), one Game Chaprassi ( $7 \frac{1}{2}$ months there). None of them appeared to have much knowledge of the sanctuary or of wild life.

\section{Future of the Manipur Brow-antlered Deer}

In addition to being protected by law, this deer is protected by the impenetrability of its habitat and by the fact that most of the surrounding villagers are vegetarian Manipuris. In actual fact its survival during the past twenty years had been due more to the last two factors than to any legislation. There is welcome evidence, however, that the present Manipur administration is keenly interested in preserving the deer, and the authorities deserve praise for steps already taken in creating and developing Keibul Lamjao Sanctuary. The new Public Works Department and Forest roads have made the sanctuary accessible by car. There are plans for reafforestation of the small hills at the southwest corner of the sanctuary, and to construct a bungalow there for visitors. 
In view of the fact that visitors have very little hope of seeing the deer in the sanctuary owing to its impenetrable phumdi conditions, there is a proposal to make an enclosure consisting partly of phumdi grassy area and partly of high ground grassy area near the site of the proposed bungalow (see Map). It is also proposed to reafforest some of these overgrazed areas with Salix tetrasperma, a tree species which is indigenous to these parts.

The above appears to be an excellent idea, especially as Browantlered Deer are known to do well in captivity. But it is questionable whether it would be in the best interests to have the enclosure at this place at the edge of the sanctuary, or to have it nearer Imphal - or even in the town of Imphal itself, in the form of a small zoological park.

It is possible that this species may have formerly ranged over a larger area, including grassy undulating land at the foot of the hills, before being driven by increasing population and extending agriculture on to the phumdi of the Logtak Lake, which may after all be its present habitat by necessity and not of original choice.

\section{Recommendations (see Map)}

(1) That the Keibul Lamjao Sanctuary be strictly protected as the only remaining habitat of the very rare Manipur subspecies of the Brow-antlered Deer. The following measures in particular are advised :

(a) Rice cultivation in the centre of the sanctuary should be prohibited.

(b) The question of the waste land on the western side of the sanctuary, at present unlawfully occupied by villagers, should be settled in the best interests of the sanctuary, and so as not to antagonize the local villagers.

(c) The grazing in the sanctuary of domestic buffaloes, if it cannot be prohibited, should be restricted as much as possible. The possibility of excising some of these grazing areas from the sanctuary area could be considered.

(d) Fishing and cutting of reeds in the sanctuary, if an established right and not preventable, should be carefully watched so that there will be a minimum of danger and disturbance to the deer.

(e) The numbers of wild pig should be reduced, when they raid the neighbouring rice crops. 
(2) That the Forest Staff in charge of the sanctuary should be as permanent as possible, and under an officer of rank not less than Deputy Ranger.

(3) That an ecological study be made of the deer in its unusual phumdi habitat.

(4) That, owing to the extreme difficulty of seeing deer in the sanctuary, a few animals be humanely captured (departmentally) and kept in a suitably located enclosure. This measure should assist in preserving the animal, in increasing its numbers, in enabling scientific study and in providing an attractive exhibit for visitors.

(5) That the Game Rules, published in 1958 as " Preservation of Wild Life in Reserved Forests and other Parts of Manipur", be revised and brought up to date.

(6) That steps be taken to ensure education and publicity in wild life and nature conservation, in order to arouse consciousness among the people of the cultural and economic value of wild life.

REFERENCES (referring to the complete report)

Barron, A. H. D., 1912. "A Deformed Thamin Stag," J. Bombay Nat. Hist. Soc., 21 (2), pp. 654-5.

Bepford, Duke OF, 1949. The Years of Transition, London 1949.

DEB, D. B., 1960. Forest Type Studies in Manipur," Indian Forester, 86 (2), pp. 94-111.

Eld, Lieut. Percy, 1841. Further notice of a Nondescript species of Deer indicated in the 4th Number of the Cal. Journ. Nat. Hist., extracted from a letter of Lieut. Eld, Assistant to the Commissioner of Assam, dated 21 st May, 1841, with a drawing of the horns, plate xii. Calcutta Journ. Nat. Hist. 2, pp. 415-7.

GeE, E. P., 1955. " The Brow-antlered Deer," J. Bombay Nat. Hist. Soc., 52 (4), pp. 917-9.

1958. "Four Rare Indian Animals," Oryx, IV (6), pp. 353-8.

Hugaiss, J. C., 1934. "The Game Birds and Animals of the Manipur State with Notes on their Numbers, Migration and Habits," J. Bombay Nat. Hist. Soc., 37 (2), p. 307.

Lydekкen, R., 1924. The Game Animals of India, Burma, Malaya and Tibet, London 1924.

Nouver, J., 1951. " Note sur la Reproduction du Cerf d'Eld . . a au Pare Zoologique du Bois de Vincennes," Bull. Mus. His. nat. Paris, 22 (2), pp. $682-3$.

Stockley, C. H., 1928. Big Game Shooting in the Indian Empire, Bombay, Calcutta, Madras.

TALвот, L. M., 1960. "A Look at Threatened Species," Oryx, V (4 and 5), pp. 147-326.

Tur Yin, U., 1956. "The Brow-antlered Deer or Thamin" (Panolia eldi thamin Thomas) in the Union of Burma (1955)," J. Bombay Nat. Hist. Soc., 53 (3), pp. 460-3.

Ward, Rowland, 1928. Records of Big Game, London.

Wrlson, Alban, 1924. Sport and Service in Assam and Elsewhere, London.

Wood, H. S., 1934. Shikar Memories, London. 